\title{
Social Capital and Job-Searching Processes of Japanese-Minahasans in Oarai, Ibaraki Prefecture, Japan
}

\section{MEGURO Ushio}

\author{
Aun-do Co.; Nanae-cho, Hokkaido 041-1354, Japan. \\ E-mail: nl_lab@yahoo.co.jp
}

Received January 20, 2009; Accepted December 16, 2009

\begin{abstract}
This paper aims to clarify a unique phase in the job-searching process of Japanese-Indonesians residing in Oarai, Ibaraki, Japan. Social network analyses are employed to explain their job-changing strategies, and the social capital theory is applied to interpret members' roles. This paper focuses on Japanese-Minahasan workers from North Sulawesi, Indonesia, who have recently become a dominant group of foreign residents in Oarai. After settling in Japan, Japanese-Minahasans-many of whom are descendants of fishermen from Okinawa and of Japanese soldiers who went over to the northern part of Sulawesi Island before and during World War II-often try to change their jobs from the fishery industry to electric machinery etc., seeking higher wages. Social capital theories revealed that two patterns of social network were influential in their job-changes: networks with undocumented workers who have useful job information in Japan, and those with the heads of their household who themselves remain in Oarai and would give family members helpful advice, and places to return. In the job-searching strategies, Oarai serves as a "bastion" for their spatial expansion. This diffusion of Japanese-Minahasans throughout Japan represents a combination of the mutual support system and market-oriented migration system, which is unique and unprecedented in migration system studies in Japan.
\end{abstract}

Key words Japanese descendant, Minahasa, ethnic group, Oarai, social capital, pyramidal hierarchy

\section{Introduction}

\section{Previous approaches and problems}

Ethnic groups tend to settle first in concentrated spots and later spread to broader areas; through this process, they adapt themselves to the local conditions while simultaneously transforming the regions they inhabit. In order to understand this phenomenon, it is necessary to clarify the social networks developed by immigrants in specific regions (Mabogunje 1970).

The term "social network" refers to ties formed among individuals and groups through solidarity and cooperation. These ties can play an active role in the welfare of the members of ethnic groups, especially if they wish to strengthen their positions in their host countries (Portes 1995).

When a group of ethnic workers becomes significantly large in number, the host market cannot ignore their presence, and smooth and harmonious employeremployee relationships may result (Kajita and Iyotani 1992; Onai and Sakai 2001). However, when ethnic workers are comparatively small in number, the host society tends to disregard them. Under such a situation, minority groups must make the most of social networks in order to find good jobs in the host market (Roberts 1994; Okushima 2005). In order to grasp the actual conditions of minor groups, close examination into their social networks is essential, for their movements are not clearly reflected in formal statistical figures nor in policies of local governments.

This paper focuses on Japanese-Minahasans-people of Japanese descent from the Minahasa District in the northern Sulawesi Island, Indonesia-residing in Oarai, Ibaraki Prefecture. Most Japanese-Minahasans are descendants of fishermen from Okinawa or military people who settled in the northern part of Sulawesi Island before and during World War II, when Japanese troops were advancing southward.

Because overpopulation in Indonesia has generated a labor surplus, many Japanese-Minahasans have decided to come to Japan to work in the fishery industry in Oarai, where they have personal connections. ${ }^{1}$ Many Japanese-Minahasans expected to earn adequate living, and to be treated fairly. Actually, these expectations were not realistic, as the immigrants were not able to obtain job information easily. Most of them failed to secure employment at public employment security offices or companies where employees were required to be fluent 
in the Japanese language. These conditions compelled Japanese-Minahasans to seek the help of social networks involving friends and relatives (Meguro 2005). This paper aims to clarify the actual conditions of JapaneseMinahasans living in Japan, by examining how they utilize social networks in the Japanese labor market to gain a satisfactory employment.

Many researchers in the field of sociology have studied the role of social networks in helping migrants change jobs (Portes 1995, 1996; Lin 2001a: 153; Hirota 2003: 101). Shortly after, geography started taking up studies on social networks of ethnic groups living in places focused upon. For example, Lee (2002) quotes from Granovetter's "social embeddedness theory," and explains how social networks function for Koreans residing in and around Osaka. Kataoka's $(2004,2005)$ series of works on Brazilians, especially on the descendants of Japanese immigrants in Brazil and their relatives living in Hamamatsu, Shizuoka Prefecture, show that ethnic businesses play an important role in establishing social networks.

Traditional case studies on ethnic groups in Japan have focused on larger groups, such as Koreans and Brazilians of Japanese origin. In comparison, JapaneseMinahasans are relatively new to Japan and still small in number. However, the job-searching networks used by Japanese-Minahasans are different from those of Japanese-Brazilians and other ethnic groups. JapaneseMinahasans first depended only on their connections to family members and religious groups. Later, they began to develop connections in the labor market in order to obtain better jobs. The function of these networks is noteworthy, and offers new perspective for the studies of ethnic groups, which are now diversified in Japan.

\section{Approaches}

Two approaches have been applied to systems of migration and settlement: a "mutual support system" and a "market-oriented system" (Higuchi 2002). The former is a migration system based on kinship among group members and their original local communities. In the mutual support system, social networks function both within and without national boundaries. The marketoriented system, in contrast, does not necessarily require social networks among group members. Instead, it depends on mediators-commonly known as brokerswho engage in labor markets. Several papers (Higuchi 2002; Kataoka 2005; Arango 2000) show that Latin American migrators of Japanese descent in the 1990s formed a market-oriented system in Japan.

Oarai Japanese-Minahasans' groups started mutual support types first, and have gradually been taking up market-oriented ones. In the 1990s, a substantial number of Minahasans began to flow into Japan, and they soon organized systems called "kerukunan" (village associations in Indonesian), which were based on mutual support. Their key places for assembly were Christian churches. The members were both racially and religiously homogeneous. These immigrants brought the social networks they had developed in Minahasa to Japan, and maintained the same relationships and beliefs in Oarai (Okushima 2005; Meguro 2005; Tirtosudarmo 2005). Recently, with the help of brokers, some JapaneseMinahasans have begun to work in markets run by Latin Americans of Japanese descent. This may indicate that more of the Japanese-Minahasans have started participating in the market-oriented system. In order to provide a more detailed explanation of the situation during the period of this transition from mutual support to market-oriented system, this paper employs the social capital theory.

The social capital theory is the foundation for the studies of migration systems. ${ }^{2}$ This theory consists of various definitions, and researchers select the one that best suits their study. When job change is the main subject, social capital is defined as "resource investment in social relations with expected returns in the market place" (Lin 2001b: 19). The mutual support system is interpreted as a system in which social capital is carried from an immigrant's home country. In the market-oriented system, in contrast, social capital is newly established in the host society (Higuchi 2002; Kataoka 2005; Arango 2000).

The application of a pyramidal hierarchical structure is an effective explanation for understanding the position of subjects in a social system, and the way they use social capital (Lin 2001b). In a hierarchical social system, it is possible for individual members and groups to be influenced by those in different strata and change their positions (Figure 1a). Here, we term one individual/ group "ego," and another individual/group connected to the ego "alter." If "ego 1" is an individual who belongs to a company and has a social network with "alter 1," who holds a better position than "ego 1," the former can be elevated to a rank close to the rank held by "alter 1" by utilizing social capital. Thus, the social network not only implies a relationship between individuals but can function as a means to improve an individual's position. In contrast, if "ego 2" forms a social network with "alter 2," the former descends to a lower rank owing to the social capital used. In this manner, hierarchical structures can 


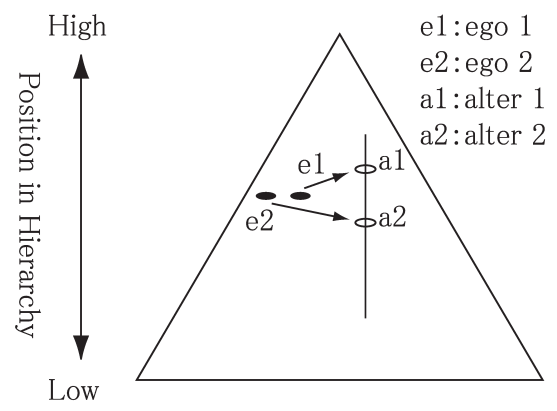

a) Relative Effects of Social Capital

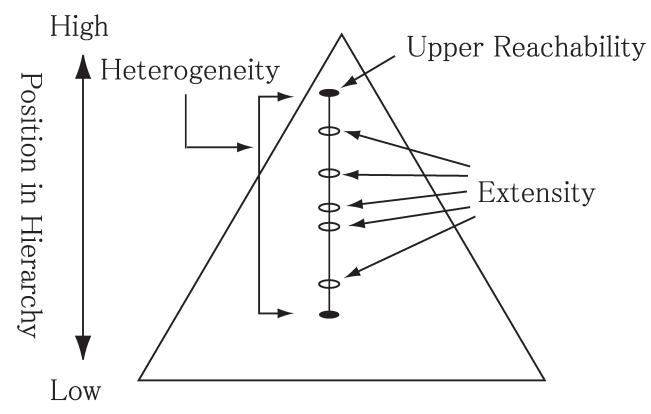

b) Criteria of Measurement in Social Capital

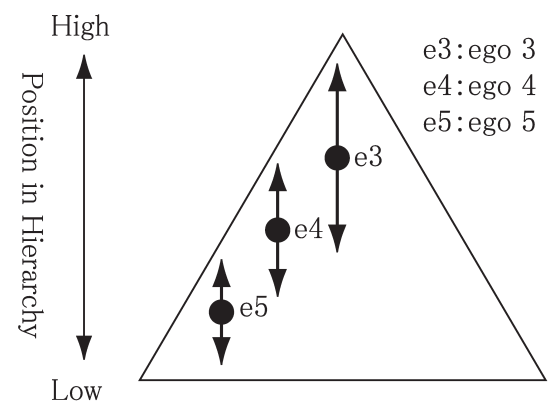

c) Structural Restrictions of Networking Effects

Figure 1. Social capital theory and hierarchical structure.

Source: Lin (2001a).

indicate the changes in an individual's position brought by social capital.

Egos situated in a hierarchical structure are equipped with three types of characteristics (Figure 1b). The first is "upper reachability," which means a limitation to the social capital that can be obtained by an ego through social ties. The second characteristic is "heterogeneity," which means a range of the characteristic of positions through social ties. Since there are usually more than one alter involved in a social network with an ego, egos may obtain both good and bad positions through social capital. The range from upper reachability to the bottom is referred to as heterogeneity. The third characteristic is "extensity," which implies that attainable positions are not ranged continuously in the hierarchy-there are gaps in the characteristic of jobs. Positions within the hierarchy indicate the state of employment and acquisition of a specific post in a particular company. Extensity is therefore expressed in the form of dots.

Lin (2001b) introduced the three characteristics and their definitions into established methods of social network studies, regulated social capital theories, and set up seven propositions. One of the propositions, which is related to "structural contingency," is particularly relevant to the present discussion. ${ }^{3}$ According to the structural contingency proposition, "people ranked in middle strata are at advantage in constructing networks". In Figure 1c, egos 3, 4, and 5 are placed in the upper, middle, and lower strata, respectively. All three egos construct networks in the same area. Since ego 3 is close to upper reachability, he or she can obtain social capital only from lower positions. Ego 5, in contrast, can obtain social capital from neither lower nor higher positions due to his or her limited network range. Ego 4, however, is capable not only of reaching upper positions but of helping egos in the lower positions to rise. Furthermore, ego 4 can set up networks with his or her peers in the middle position. Thus, occupants of the middle position, such as ego 4 , are in the most advantageous position to obtain wide social networks, where the construction of a social network produces the best results.

This paper aims to clarify the actual state of job changes of Japanese-Minahasans by examining social networks through a social capital theory perspective. ${ }^{4}$ In order to provide a clear picture of the situation of JapaneseMinahasans, their positions were sorted into upper, middle, and lower strata in a pyramidal hierarchy. Next, it was determined whether each of Japanese-Minahasans is affected by the structural contingency proposition. Further, if this is the case, the reasons for JapaneseMinahasans' position are considered. When depicted in pyramidal social structures, the situation of JapaneseMinahasans and the intrinsic characteristics of their social networks will become highly evident. Relevant study using this approach will lead to the understanding and generalization of concrete phenomena.

\section{Study area}

The Town of Oarai, established in 1949 by consolidating the adjacent areas of the towns, Isohama and Onuki, is located in Ibaraki Prefecture, close to the center of the easternmost coastline facing the Pacific Ocean. As of 2004, the de jure population of Oarai was 19,623. The town's industries are closely connected to Oarai Port. Oarai's seafood processing companies, in which most Japanese-Minahasans living in Oarai are employed, 
spread throughout the town. Along with the fishery and sightseeing businesses, Oarai's seafood processing industry thrives.

After 1980, the seafood processing industry in Oarai slackened, and the wages in this industry declined. As the population of the town began to decrease and residents grew older, seafood processing companies made every effort to attract workers but in vain.

These circumstances forced the companies to depend on foreign workers. Owing to the employment of foreigners, companies have been able to maintain a stable number of workers, even when the number of companies was dwindling. In fact, since 1991, the number of workers at seafood processing companies in Oarai has been increasing.

The following chapters provide a more detailed explanation of the inflow of Japanese-Minahasans into Japan and subsequent changes in their employment situations. The functions of social networks are also examined on the basis of results obtained from a field survey in Oarai. Chapter II reveals backgrounds of the inflow and distribution of foreign workers including Japanese-Minahasans, with brief comments on their daily life and work. Chapter III presents the results of the author's field survey and analyses. In Chapter IV, several specific cases suggesting that job changes among Japanese-Minahasans are closely related to social networks are discussed. Finally, in Chapter V, the findings are summarized, and conclusions that might be useful for future research are presented.

\section{Inflow of Indonesians}

\section{Indonesian labor and the employment situation of Japanese-Indonesians}

The number of foreigners registered in Oarai increased significantly in the mid-80s, reflecting the shortage of labor force in the seafood processing industry during that time. As of April 2005, Indonesians were the largest group of foreigners, 443 people, followed by Chinese (154), Filipinos (112), Thais (58), and Brazilians (25), according to Oarai's foreigner registration documents. Oarai has experienced frequent shifts in the numbers of foreigners. For example, in 1985, Iranian immigrants dominated, followed by Filipinos and Thais.

There had long been a flow of undocumented workers, who were often arrested by Immigration Control Office. The corporations in the town wanted to avoid trouble, and made efforts to employ immigrants of Japanese descent who could be formally accepted. As a result, undocumented foreigners gradually left Oarai for Nagoya, Aichi Prefecture, and Oizumi, Gunma Prefecture, or engaged in agriculture near Oarai.

In 1998, Oarai's seafood processing companies, suffering from a shortage of workers, asked Mr. A, who happened to have personal connections with JapaneseMinahasans for introduction. He began introducing Japanese-Minahasans to Oarai's companies so that they could be employed as formal year-round workers (Meguro 2005). In 1999, Indonesians became the largest group of foreigners in Oarai, with 183 officially registered residents, mainly Japanese descendants. JapaneseMinahasans remained the largest group of foreigners in Oarai until 2005.

\section{Distribution of Indonesian laborers}

This subsection clarifies the characteristics of the communal dwellings of Indonesians in Japan, including Japanese-Minahasans in Oarai. Figure 2 reveals uneven distribution of Indonesians in the Kanto region. Foreigners are subjected to different local regulations, cultures, community patterns, and economic situations. The number of Japanese-Minahasans in Oarai (311 people) is conspicuously large.

Many foreigners reside in and arround Isohama, the central part of Oarai, ${ }^{5}$ and some facilities are available to them (Figure 3). No condominiums have been constructed in Oarai for factory workers, and the buildings of fishery companies are lined along the main streets of the town. For commuting convenience, most foreigners choose to reside in the northern part of the business district in which several businesses, including bars and restaurants, owned by foreigners are located. Only three houses in Oarai, all of which are rented to workers by Mr. A, are used as company dormitories. Because many Japanese-Minahasans lack basic facilities and conveniences, and because the predominant religion in their home province is Christianity, they often seek support from religious organizations, primarily Christian churches.

\section{Religion and churches of Japanese-Indonesians in Oarai}

In Oarai, there are four Christian organizations and three churches, to which the Japanese-Minahasans belong. ${ }^{6}$ Religious groups play an important role in providing them with a wide range of guidance for their daily life, and letting them realize their sense of belonging. The first Christian denomination established in Oarai is GIII (Gereja Interdenominasi Injili Indonesia, or Tokyo- 


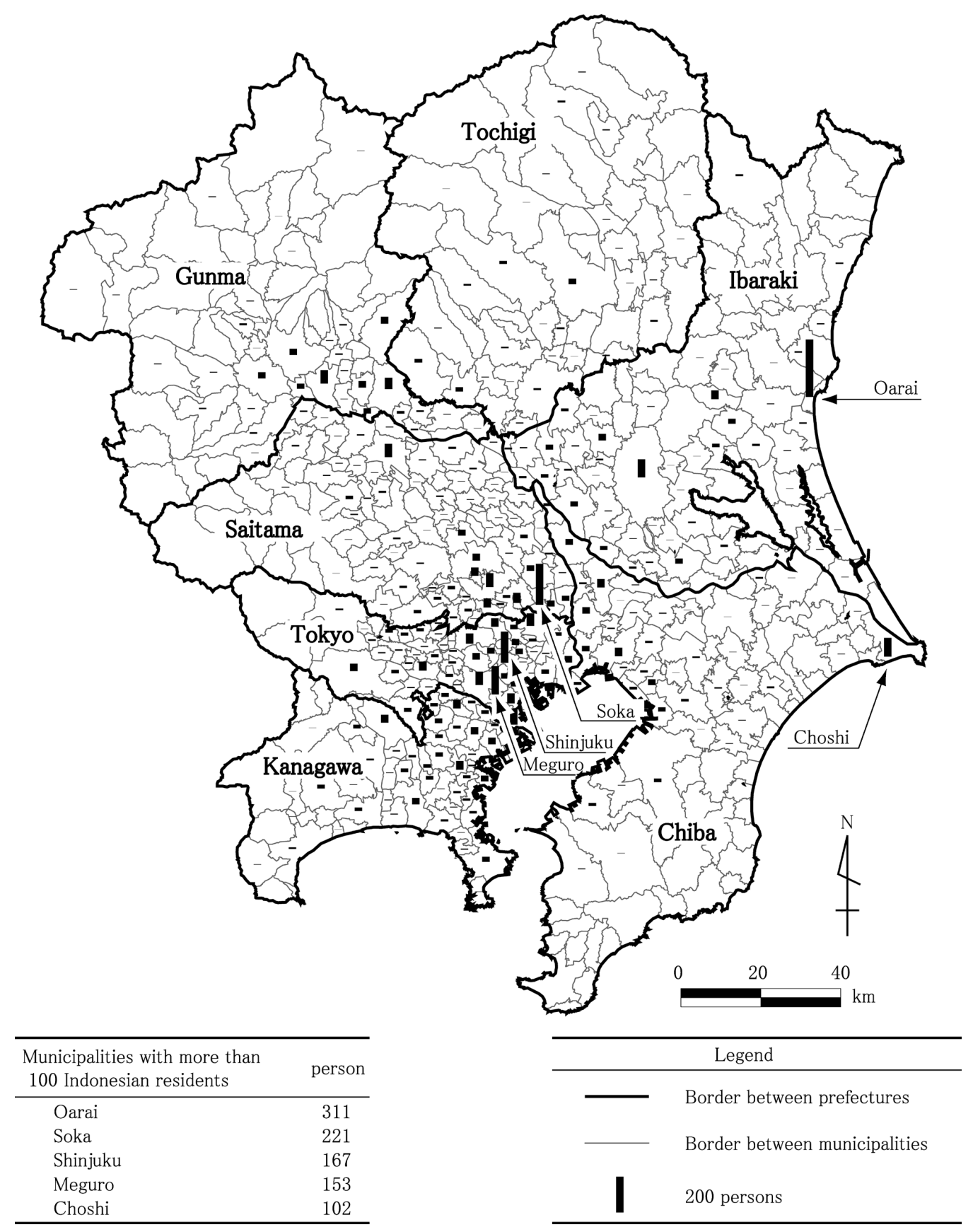

Figure 2. Distribution of Indonesian dwellings in the Kanto region (islands excluded). Source: The 2000 National Census.

Indonesia Interdominational Church). GIII holds services twice a week, at noon and at night on Sundays, with a usual congregation of 70 to 80 and more than 150 during festivals. The second largest Christian organization is GMIJ (Gereja Masehi Injili di Jepang, or Japanese branch of the Christian Evangelical Church in Minahasa). Today, the congregation consists of around 50 to 70 Minahasans every Sunday, and about 100 on holidays. Unlike GIII that is open to all Indonesians staying in Japan, GMIJ works as a branch of a church organization rooted in Minahasa. The third largest church organization is GISI (Gereja Injili Seutuh Indonesia, or Indonesian Full
Gospel Fellowship Church). Usually about 30 people attend GISI services, with a slightly larger number on holidays. Actually, the number of people belonging to this church is rather indefinite, and it is difficult to grasp the precise figure. GIII, GMIJ, GISI are all Protestant, only in different denominations, so the Protestant believers often communicate with each other outside the church they belong to.

There is also a Roman Catholic Church for Indonesians in Oarai. The Catholic Church rarely associates with other churches, and conducts its activities independently. Around 30 people attend its service every week. 


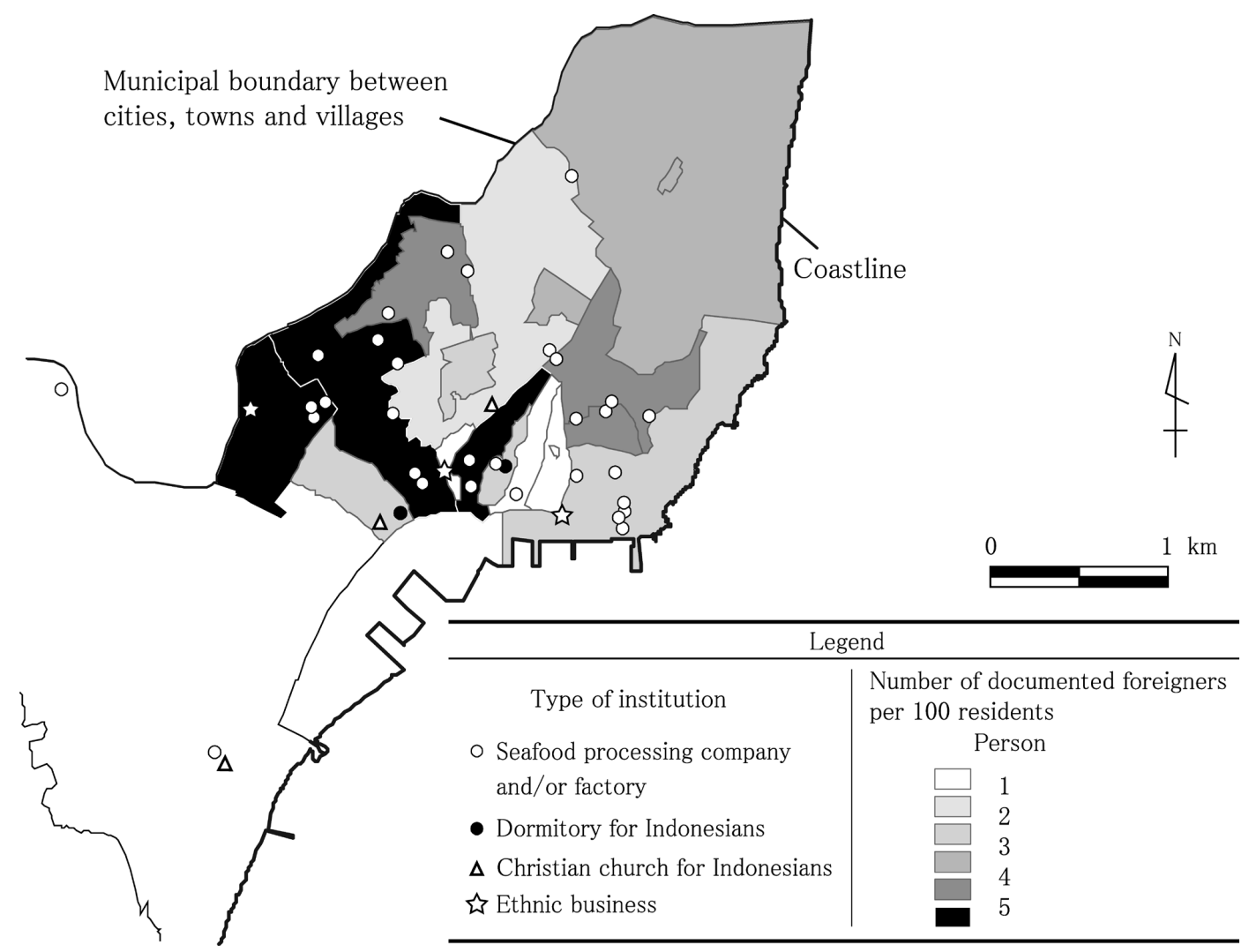

Figure 3. Distribution of seafood-processing companies, dormitories and churches for Indonesians and ethnic business in the central part of Oarai, and the ratio of documented foreigners in each bloc.

Source: The author's field survey and the 2000 National Census.

The Protestant churches have a strong influence on the job changes of Japanese-Minahasans. GMIJ and GISI are relatively new churches established to meet the demands of Indonesians, including JapaneseMinahasans, and emphasize missionary activities. Thus, Japanese-Minahasans belonging to these churches do not necessarily consider themselves to be linked to Oarai, and frequently change jobs both inside and outside Oarai. In contrast, GIII and Catholic Churches, established under the leadership of the Indonesian Embassy for the benefit of the Indonesians in Japan, aim to cultivate close relationships with neighbors. Members of these churches therefore consider themselves to be more deeply rooted in Oarai, and they change jobs less frequently. These differences between newer and older churches were reflected in the job-changing patterns observed in this study.

\section{Profile of Japanese-Minahasans and Situations Related to Job Changes}

\section{Outline of the field survey and attributes of the subjects}

This subsection describes the actual situation of job changes among Japanese-Minahasans in relation to the circumstances discussed in the previous section. Data on job changes among Japanese-Minahasans were obtained during the author's intermittent visits to Oarai between July and November 2005. Face-to-face interviews were conducted with Japanese-Minahasans, and their answers were recorded in questionnaire forms. Subjects were chosen by opportunistic sampling. All the 40 subjects selected for this investigation were Japanese-Minahasans and their families who had substantial work experience in Oarai. Although interviews were mainly conducted in Japanese and English by the author, some interviews in Indonesian were conducted with the assistance of an interpreter.

Although the basic attributes of the 40 subjects do not accurately represent the entire Japanese-Minahasan population in Oarai, they do provide a general understanding of the diversity of this ethnic group (Table 1). Subjects comprised 21 males and 19 females, including 10 married couples. Only one subject was in his teens; 13 were in their twenties; 19 in their thirties; four in their forties; and three in their fifties. The age and gender distributions of the subjects were similar to those of the entire population of Japanese-Minahasan workers 
Table 1. Attributes of subjects

\begin{tabular}{|c|c|c|c|c|c|c|c|}
\hline Subject & Gender & Age & Generation & $\begin{array}{l}\text { Educational } \\
\text { background }\end{array}$ & $\begin{array}{c}\text { Japanese } \\
\text { language skills }\end{array}$ & Hometown & Church \\
\hline 1 & Male & $50 \mathrm{~s}$ & $2 n d$ & $J H$ & Greetings & Tomohon & GMIJ \\
\hline 2 & Male & $20 \mathrm{~s}$ & $3 r d$ & $\mathrm{VH}$ & Greetings & Manado & GMIJ \\
\hline 3 & Female & $20 \mathrm{~s}$ & spouse of $3 r d$ & U & Greetings & Bitung & GISI \\
\hline 4 & Male & $30 \mathrm{~s}$ & $3 r d$ & $\mathrm{H}$ & Greetings & Tomohon & GISI \\
\hline 5 & Male & $20 \mathrm{~s}$ & $3 r d$ & $\mathrm{VH}$ & Greetings & Bitung & GISI \\
\hline 6 & Male & $40 \mathrm{~s}$ & spouse of $3 r d$ & $\mathrm{H}$ & Greetings & Tomohon & Catholic \\
\hline 7 & Female & $30 \mathrm{~s}$ & $3 r d$ & $\mathrm{H}$ & Greetings & Tomohon & Catholic \\
\hline 8 & Female & $30 \mathrm{~s}$ & $3 r d$ & $\mathrm{H}$ & Greetings & Tomohon & Catholic \\
\hline 9 & Female & $20 \mathrm{~s}$ & spouse of $3 r d$ & $\mathrm{H}$ & Greetings & Manado & GISI \\
\hline 10 & Female & $50 \mathrm{~s}$ & spouse of 2 nd & $J H$ & Greetings & Manado & GMIJ \\
\hline 11 & Male & $40 \mathrm{~s}$ & $3 r d$ & U (half) & Fluent & Bitung & GISI \\
\hline 12 & Male & $40 \mathrm{~s}$ & $3 r d$ & $\mathrm{H}$ & Adequate & Bitung & GISI \\
\hline 13 & Male & $30 \mathrm{~s}$ & $3 r d$ & $J H$ & Greetings & Bitung & GMIJ \\
\hline 14 & Male & $30 \mathrm{~s}$ & $3 r d$ & $J H$ & Greetings & Manado & GMIJ \\
\hline 15 & Female & $30 \mathrm{~s}$ & spouse of $3 r d$ & $J H$ & Greetings & Manado & GMIJ \\
\hline 16 & Female & $30 \mathrm{~s}$ & $3 r d$ & U & Greetings & Manado & GIII \\
\hline 17 & Male & $30 \mathrm{~s}$ & spouse of 3 rd & U & Adequate & Manado & GIII \\
\hline 18 & Female & $20 \mathrm{~s}$ & spouse of 3 rd & $J H$ & Greetings & Bitung & GMIJ \\
\hline 19 & Male & $30 \mathrm{~s}$ & $3 r d$ & $J H$ & Greetings & Bitung & GMIJ \\
\hline 20 & Female & $30 s$ & $3 r d$ & $\mathrm{H}$ & Greetings & Manado & GIII \\
\hline 21 & Male & $50 \mathrm{~s}$ & spouse of $3 r d$ & $\mathrm{VH}$ & Greetongs & Manado & GIII \\
\hline 22 & Female & $20 \mathrm{~s}$ & spouse of 3 rd & $\mathrm{H}$ & Greetings & Manado & GIII \\
\hline 23 & Male & $20 \mathrm{~s}$ & $3 r d$ & $\mathrm{H}$ & Greetings & Manado & GIII \\
\hline 24 & Female & $30 \mathrm{~s}$ & $3 r d$ & $\mathrm{H}$ & Greetings & Balikpapan & GIII \\
\hline 25 & Male & $20 \mathrm{~s}$ & $3 r d$ & $\mathrm{H}$ & Greetings & Manado & GIII \\
\hline 26 & Female & $20 \mathrm{~s}$ & spouse of 3rd & $\mathrm{VH}$ & Greetings & Manado & GIII \\
\hline 27 & Male & $30 \mathrm{~s}$ & spouse of $3 r d$ & $\mathrm{H}$ & Greetings & Bitung & GIII \\
\hline 28 & Male & $20 \mathrm{~s}$ & $3 r d$ & $\mathrm{H}$ & Greetings & Tomohon & Catholic \\
\hline 29 & Female & $30 \mathrm{~s}$ & $3 r d$ & U & Fluent & Tomohon & Catholic \\
\hline 30 & Female & $30 \mathrm{~s}$ & 2nd & $\mathrm{H}$ & Adequate & Manado & GMIJ \\
\hline 31 & Male & $10 \mathrm{~s}$ & $3 r d$ & $J H$ & Greetings & Manado & GMIJ \\
\hline 32 & Male & $30 \mathrm{~s}$ & $3 r d$ & $\mathrm{H}$ & Greetings & Manado & GMIJ \\
\hline 33 & Male & $30 \mathrm{~s}$ & $3 r d$ & $\mathrm{VH}$ & Greetings & Bitung & GMIJ \\
\hline 34 & Female & $20 \mathrm{~s}$ & spouse of $3 r d$ & $\mathrm{VH}$ & Greetings & Bitung & GMIJ \\
\hline 35 & Female & $20 \mathrm{~s}$ & spouse of 3 rd & $\mathrm{H}$ & Greetings & Manado & Catholic \\
\hline 36 & Male & $30 s$ & $3 r d$ & $\mathrm{H}$ & Greetings & Manado & Catholic \\
\hline 37 & Male & $40 \mathrm{~s}$ & $3 r d$ & U & Adequate & Tomohon & GMIJ \\
\hline 38 & Female & $30 \mathrm{~s}$ & $3 r d$ & $\mathrm{H}$ & Greetings & Bitung & GMIJ \\
\hline 39 & Female & $20 \mathrm{~s}$ & 2nd & U (half) & Greetings & Manado & GISI \\
\hline 40 & Female & $30 s$ & $3 r d$ & $U$ & Greetings & Sangihe & Catholic \\
\hline
\end{tabular}

U, university; U (half), university unfinished; $H$, high school; $V H$, vocational high school; JH, junior high school.

Source: The author's interview.

in Oarai, the numbers of men and women are close, and people in their thirties constituted the largest age group.
With regard to education level, eight of the subjects were junior high school graduates; 18 were senior high 
school graduates; six vocational high school graduates; six university graduates; and two had left university before graduation. In Indonesia, approximately $40.5 \%$ of Indonesians had finished high school in 2000. ${ }^{7}$ Thus, the average educational background of Oarai JapaneseMinahasans and their families examined in this study was comparatively high.

With regard to practical Japanese language skills, two subjects who majored in the Japanese language at a university in North Sulawesi Province spoke fluently. On the other hand, the language skills of one subject case, who received the same education at the same university, were considerably poor. Three subjects were able to communicate in simple Japanese, which they had picked up since their arrival in Oarai. The majority (34) of the subjects could not speak Japanese except for greetings and basic phrases required for their jobs. On the whole, their Japanese language skills were poor compared to the majority of Indonesians in Japan-either trainees and interns or undocumented workers. Subjects said that they had little time for any other action than their work and community activities.

The generational groups of Japanese-Minahasans were as follows: three were Nisei (second-generation Japanese descendants); one was the spouse of a Nisei; 24 were Sansei (third-generation Japanese descendants); and twelve were the spouses of Sansei. Nisei and their spouses were born before or during World War II, and were too old to emigrate for work, which accounts for their relatively small number in Oarai. As for non-Japanese spouses, they are allowed to enter Japan only when accompanied by their spouses, so their number was not large (13).

The hometowns of the subjects were also asked. The largest group, with 19 subjects, was from Manado (the provincial capital of North Sulawesi), followed by 11 subjects from Bitung (a port town where many migrants from Okinawa were engaged in fisheries before World
War II). Eight subjects were from Tomohon, a regional city in North Sulawesi, and only one subject, Subject 24, was from Balikpapan, East Kalimantan. She was actually born when her Minahasan parents were working away from home. Subject 40, although originally from Sangihe Island, which is isolated off North Sulawesi, was included in the Minahasan group because her husband was from Bitung.

The church group with the largest number of subjects (15 persons) was GMIJ, followed by GIII with 10 subjects; GISI with 7; and the Catholic Church with 8.

\section{Intentions behind job changes}

In this subsection, the actual intentions behind job changes among Japanese-Minahasans in Oarai are examined. Table 2 shows subjects' reasons for changing their jobs. Of the 40 subjects, 31 wished to change their jobs. Out of these 31,26 gave specific reasons for wanting to change. Many of them said that their expectations with regard to holidays and wages were not satisfied. They were also worried that they would soon be replaced by newcomers and lose their present jobs. Of the 26 subjects who gave reasons for wanting to change jobs, 14 blamed low wages. Especially, among subjects working in the seafood processing industry, 8 subjects gave this reason for wanting to change their jobs. Generally speaking, workers in the seafood processing industry were most discontent with their present wages.

Table 3 shows the types of jobs to which the subjects wished to change. In many cases, the most popular were jobs in manufacturing industries that accepted foreign workers from Latin American, Southeast Asian, and other East Asian countries. All of the subjects who hoped to secure jobs in industries other than seafood processing answered that they would like to work in the electronics or machinery industries. Four subjects, all of whom had social connections to Japanese people, mentioned specific company names.

Table 2. Reasons for subjects'job changes (multiple responses) (Units: persons)

\begin{tabular}{|c|c|c|}
\hline Reason & Respondents & $\begin{array}{l}\text { Respondents employed in seafood } \\
\text { processing industry }\end{array}$ \\
\hline Low wage & 14 & 8 \\
\hline Unfavorable work environment & 8 & 6 \\
\hline Subject not suited to job & 2 & 0 \\
\hline Unfavorable working hours & 2 & 2 \\
\hline Contract unfulfilled & 3 & 3 \\
\hline Desire for new experiences & 6 & 2 \\
\hline Total & 26 & 13 \\
\hline
\end{tabular}

Source: The author's interview. 
Table 4 shows the places where the subjects would like to be employed. Five subjects wished to continue working in Oarai. Three wished to work either in Ibaraki prefecture and surrounding areas; and 14 wished to work in places other than Oarai. Of these subjects, seven mentioned specific places such as Oizumi, Gunma Prefecture, or Nagoya, Aichi Prefecture. Undocumented Indonesian workers who had social connections with Japanese-Minahasans living in Oarai were employed in these places, as well as in Suzuka, Mie Prefecture, and Tsuchiura, Tsukuba, and Hitachinaka in Ibaraki Prefecture. Subjects in Oarai who were able to obtain job information through social networks with these

Table 3. Types of jobs preferred by subjects (Units: persons)

\begin{tabular}{|l|r|}
\hline & Respondents \\
\hline Seafood processing & 6 \\
\hline Other than seafood-processing & 3 \\
\hline Manufacturing other than seafood-processing & 11 \\
\hline Specific jobs other than manufacturing & 4 \\
\hline No specific type & 10 \\
\hline Any type & 6 \\
\hline Total & 40 \\
\hline
\end{tabular}

Source: The author's interview. undocumented workers expected to find work in various cities outside Oarai.

\section{Circumstances under which subjects seek new jobs}

This subsection describes each subject's search for new work (Figure 4). First, subjects were divided roughly into two groups: those who worked in Oarai, and those who worked in other places. Subjects working in Oarai were further divided into two groups: those working in the seafood processing industry, and those working in other industries. None of the subjects who had left and worked outside Oarai took seafood processing jobs. In addition, a category is provided in Figure 4 for subjects who were

Table 4. Job locations preferred by subjects (Units: persons)

\begin{tabular}{|l|r|}
\hline & Respondents \\
\hline Oarai-machi & 5 \\
\hline Ibaraki Prefecture and surrounding areas & 3 \\
\hline Any areas other than Oarai-machi & 7 \\
\hline Specific places other than Oarai-machi & 7 \\
\hline No specific place & 14 \\
\hline Any place & 4 \\
\hline Total & 40 \\
\hline
\end{tabular}

Source: The author's interview.

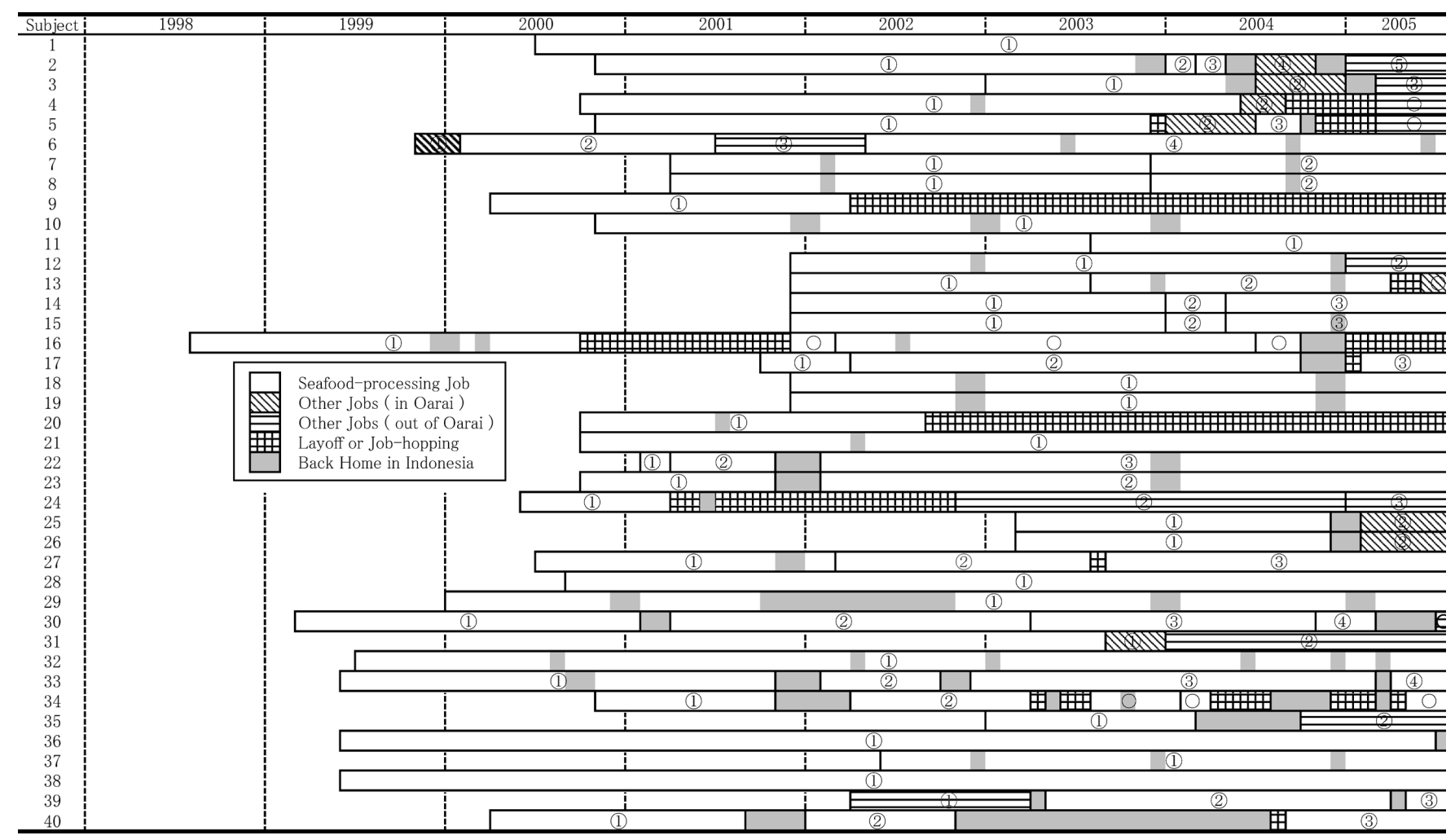

Figure 4. Employment situation of subjects.

Numbers in the circles show the times of employment. The circle with no number in it means that the case does not remember the times. Source: The author's interview 
laid off or unemployed, such as housewives who were pregnant or rearing children.

Their average period of stay in Japan was four years and five months. The shortest stay was one year and one month (Subject 31), and the longest was six years and 11 months (Subject 16). The latter subject was the first Japanese-Minahasan worker who was introduced to the seafood processing industry by Mr. A in 1998. The average contract with the seafood processing companies was a total of three years and seven months, which seems to be rather long during their stay.

Generally speaking, the first work period tended to be long, as the workers had to pay for their voyage to Japan and various housing expenses to Mr. A or other individuals who helped them find work. ${ }^{8}$ After paying off the initial charges, the workers became free to seek better jobs, and their working periods tended to be shorter from the second job.

The number of times subjects changed jobs was as follows. Fourteen subjects had only one job experience in Oarai's seafood processing industry since they arrived. Six subjects changed their jobs once, and twelve changed twice. Some of the eight subjects who changed jobs more than three times said that they were unsure exactly how many times they had changed jobs. ${ }^{9}$

Next, let us consider the types of jobs chosen by subjects. Among those who changed jobs, twelve subjects always chose seafood processing jobs in Oarai, and as many as eight of the twelve changed jobs twice. On average, subjects changed jobs twice before finding a seafood processing company that treated them satisfactorily.

Among subjects who changed jobs within Oarai, seven found a job at the same company not related to seafood processing. The company is located in the center of the town, which saved them much trouble and money included in moving.

Eight subjects have work experience outside Oarai. A few of these subjects still have homes in Oarai, and often visit their families. Although some subjects, such as Subjects 6 and 39, once found jobs in other places in Japan, they eventually returned to Oarai, as they found the job unsatisfactory or preferred to live with their family. Many subjects took holidays at least once in order to visit their homeland, Indonesia, during their first employment period. In many cases, they took holidays in December, as Christmas is their most important holiday.

\section{Attributes and employment situations of the subjects}

This subsection examines whether any relationships exist between subjects' individual attributes and their job changes. Although gender differences have little to do with their job changes, some female subjects (Subjects $9,16,20$, and 24) had to take extended maternity leave. Generational differences were also observed, that is, younger workers were more inclined to take jobs other than seafood processing.

A significant relationship was observed between the job-changing activities of Japanese-Minahasans and religious groups. Only one of the eight Catholic believers in this study left Oarai. On the other hand, the Protestants' situations varied from church to church. Eight GMIJ members changed jobs, and two left Oarai to work in other places. Of the 10 GIII members, five switched to other seafood processing companies within Oarai, and one moved outside the town. Of the seven GISI members, four left Oarai to find new jobs. Those who belong to Protestant churches can gather much information on job changes and conditions in other places through the head and branch offices in Japan. The Catholic believers do not associate with other Japanese-Minahasans frequently, so the activities of followers' job-changings are limited. Religious activities were therefore considered to have an important influence on the decision to stay in Oarai or seek jobs in other places.

A relationship was also observed between subjects' length of stay and their desire to change jobs. Immigrants who had not expected to stay long might change their minds. It seems that the longer they stay and get accustomed to Japanese way of life, the more possibility they find of gaining a firm footing here. On average, those who intended to return to their home country after having saved enough money stayed in Japan for four years and three months, while those who intended to live in Japan as long as they could stayed slightly longer, for four years and eight months.

\section{Means of job change}

The means of obtaining information and making decisions about job opportunities were considered to comprise five items: direct application, human ties (relatives), human ties (friends), brokers, ${ }^{10}$ and ads and public mediators of employment. In the grouping process, the item "direct application" was the first to be provided. Next, "human ties" were classified into "families and relatives" and "friends and acquaintances." The item "ads and public mediators of employment" came last. Subjects 
Table 5. Means and processes of job change

\begin{tabular}{|c|c|c|c|c|c|c|c|}
\hline & \multirow{3}{*}{ Means } & \multicolumn{3}{|c|}{ Employed only in Oarai } & \multicolumn{2}{|c|}{ Employed in and out of Oarai } & \multirow{3}{*}{ Total } \\
\hline & & \multicolumn{2}{|c|}{ Only in seafood processing } & \multirow{2}{*}{$\begin{array}{c}\text { Changed to } \\
\text { other } \\
\text { industry }\end{array}$} & \multirow{2}{*}{$\begin{array}{c}\text { From Oarai } \\
\text { to } \\
\text { other places }\end{array}$} & \multirow{2}{*}{$\begin{array}{c}\text { From other } \\
\text { places to } \\
\text { Oarai }\end{array}$} & \\
\hline & & $\begin{array}{c}\text { Have never } \\
\text { changed }\end{array}$ & $\begin{array}{c}\text { Have } \\
\text { changed }\end{array}$ & & & & \\
\hline \multirow{6}{*}{ Oarai } & Direct application & 7 & 8 & 1 & 7 & 2 & 25 \\
\hline & Personal ties (relatives) & 3 & 0 & 0 & 1 & 0 & 4 \\
\hline & Personal ties (friends) & 1 & 0 & 0 & 0 & 0 & 1 \\
\hline & Brokers & 0 & 0 & 0 & 0 & 0 & 0 \\
\hline & Ads and employment offices & 0 & 0 & 0 & 0 & 0 & 0 \\
\hline & No reply & 3 & 4 & 2 & 0 & 1 & 10 \\
\hline \multirow{6}{*}{ Other places } & Direct application & 2 & 0 & 1 & 0 & 0 & 3 \\
\hline & Personal ties (relatives) & 2 & 1 & 0 & 2 & 1 & 6 \\
\hline & Personal ties (friends) & 0 & 2 & 2 & 1 & 0 & 5 \\
\hline & Brokers & 3 & 8 & 0 & 2 & 2 & 15 \\
\hline & Ads and employment offices & 0 & 0 & 0 & 0 & 0 & 0 \\
\hline & No reply & 7 & 1 & 0 & 3 & 0 & 11 \\
\hline
\end{tabular}

Source: The author's interview.

responded that they would consult various people when they decided to move to other places. For job changes within Oarai, all subjects responded that they would consult the leader of their family. Thus fixed were five items of the means for obtaining hopeful information on changing jobs for the subjects (Table 5).

As for taking a job within Oarai, most subjects (25) preferred to secure employment through direct applications. On the other hand, 15 subjects stated they would use a broker for jobs in places outside Oarai. Thus, in order to seek a new job outside Oarai, those with a wider variety of network connections are at advantage.

In addition, because there are currently no ads and public mediators of employment targeting Indonesians in Japan, subjects had no choice but to obtain job information primarily from their communities and current places they are employed in. In fact, many Japanese-Minahasans actually decided to change jobs through such information. The more often workers participate in community activities and the longer they work at one company, the greater are their chances of obtaining information on employment. Even those who have changed jobs only once, eagerly collect as much information on employment as possible, and attempt to change jobs at every possible opportunity. In short, workers' desire to change jobs is closely related to their job experience. They came to understand that they could get the opportunity of working in better conditions through gathering job experience. Yet the subjects' main information resources were limited to personal connections in Oarai. Those who have a wider range of personal relationships can work under better conditions.

\section{Job Changes and Social Capital}

\section{Job change processes}

Here the author focuses on the relationships between their job-changing process and the usage of social capital, based on his field survey. Several Japanese-Minahasans who represented the general tendencies in the entire jobchanging processes were examined. The author explains these processes in detail in the following six concrete examples in order to understand how social capital functions (Figure 5).

\section{Job changes through direct employment}

Some Japanese-Minahasans collect information through companies and communities and change jobs independently. Subject 14, for example, came to Japan in November 2001 with his family and friends with Mr. A's help. Upon his arrival in Oarai, he worked in a seafood processing company for two years and one month. After repaying the initial charges, he began to consider changing his job. He collected information through personal connections he established through GMIJ, and visited another seafood processing company that offered him better wages. He took the new job. In this job change, Subject 14 did not ask a Japanese person for a letter of recommendation, nor did he have a friend who worked at the company with him. Subject 14 was able to get the job through direct application because seafood processing companies in Oarai had already begun employing 


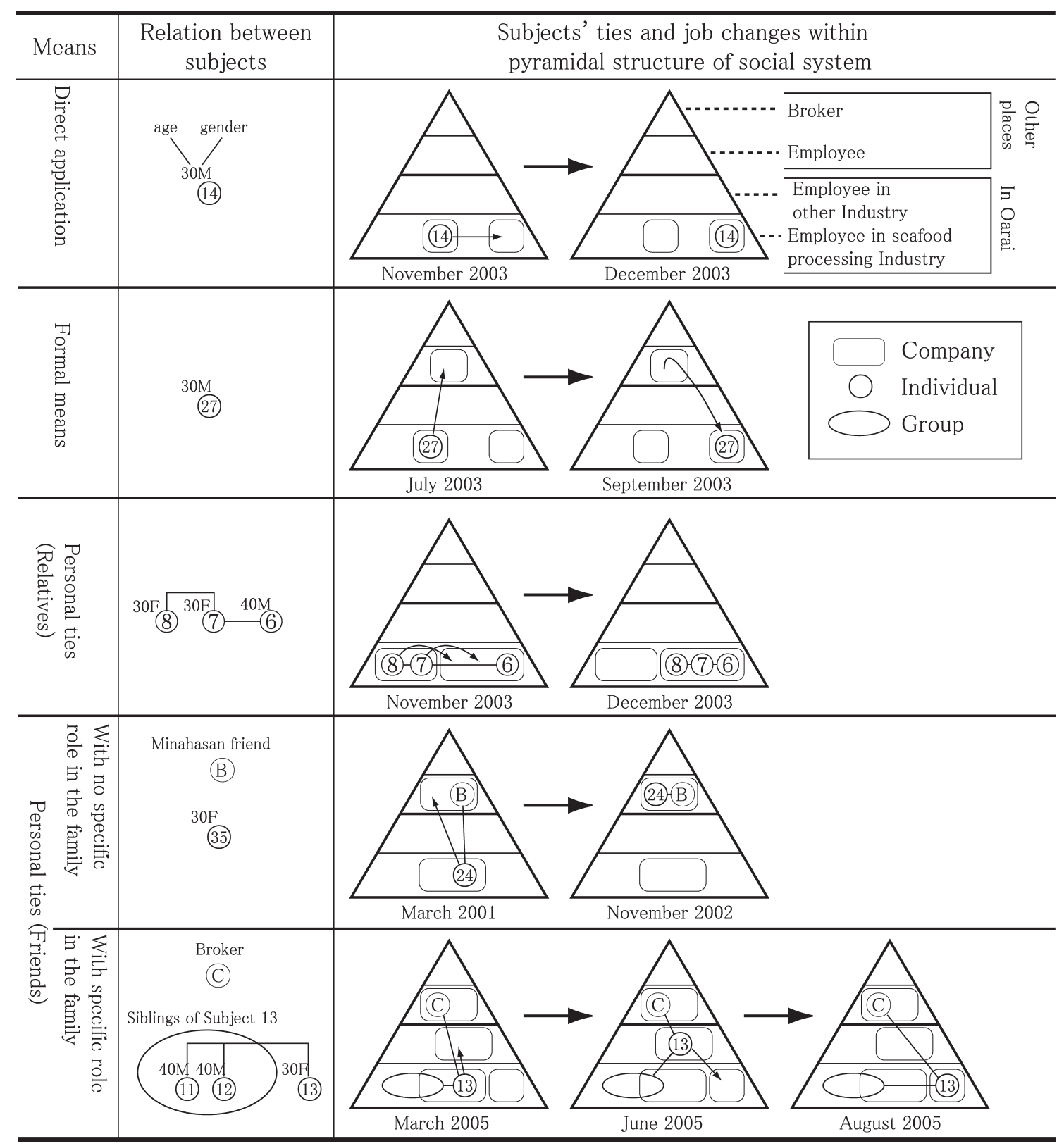

Figure 5-a. Ties and job changes of subjects within the pyramidal hierarchy. Source: The author's interview.

foreigners.

\section{Job changes through formal means}

Some actually visited an employment security office in the hope of acquiring a job outside Oarai. Let us see the process of employment of Subject 27. In September 2000, Subject 27 came to Japan with his family with Mr. A's help, and was employed in a seafood processing company in Oarai. He soon became dissatisfied with the poor working conditions and began to look for a new job outside Oarai. Although he was one of the leaders of GIII and participated in the "kerukunan" mentioned before, he did not attempt to change jobs by using these ties, because he did not regard them as reliable, and preferred to change jobs by himself. He quit his first company due to unstable wages and visited employment security offices in the Cities of Mito and Fukushima. However, he failed to secure a job due to his poor Japanese language skills. After a month's job seeking, he returned to Oarai, and found a seafood processing job at another company. This case demonstrates the difficulty when most JapaneseMinahasan workers change jobs through formal means.

\section{Job changes through relatives}

Here, we see how Subject 6 influenced the job-changing processes of his wife, Subject 7, and her sister, Subject 8. Subjects 6 and 7 got married after their arrival in Japan in 2002. Subject 6 suggested that Subject 7, his wife, who 


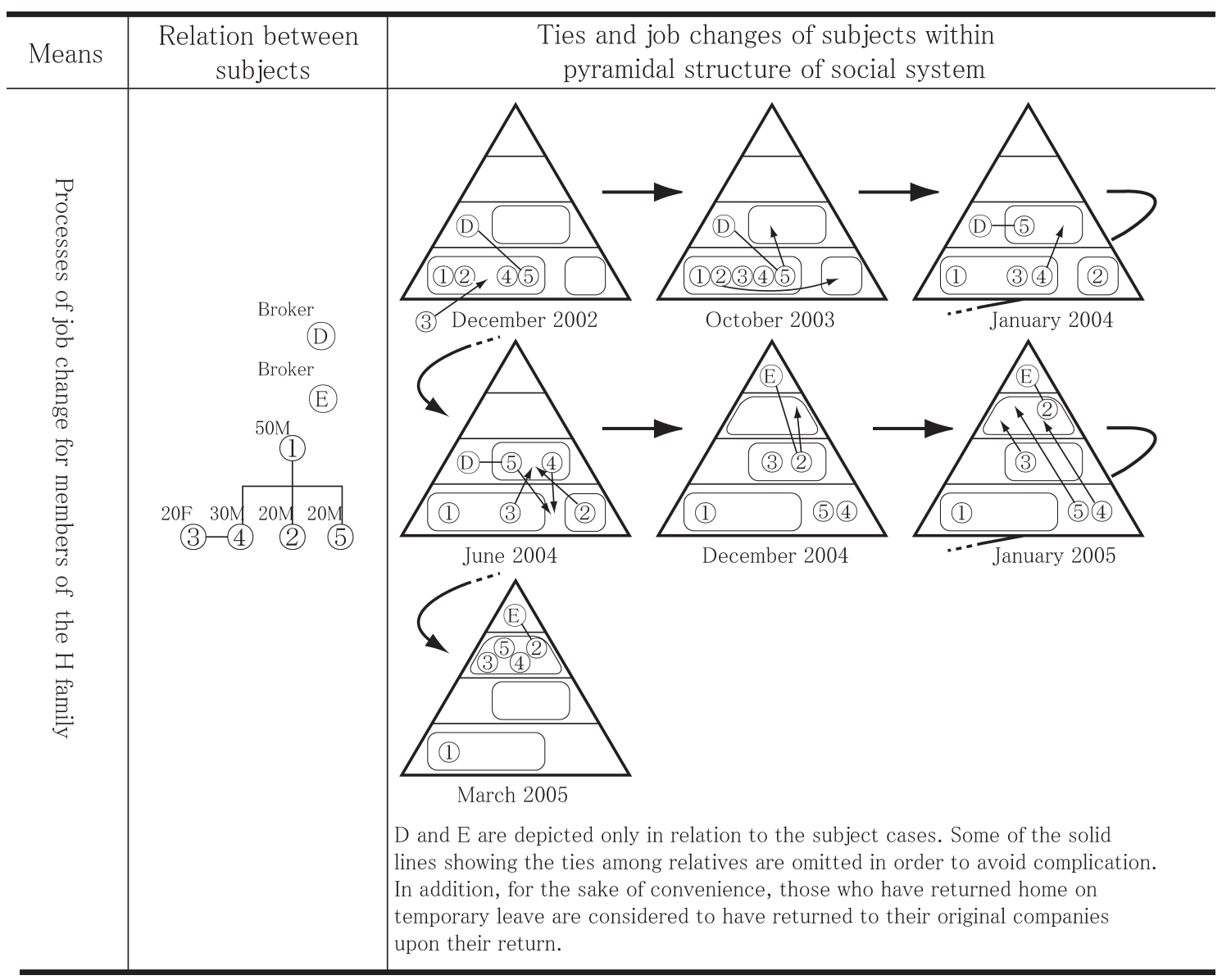

Figure 5-b. Subsequence.

was employed in another company, should work with him at the same company, and Subject 7 accepted his advice in 2003. Around the same time, Subject 8 followed her and joined the same company. In this manner, they often obtain information about various job opportunities from family members.

\section{Job changes through friends and acquaintances}

Here, the author deals with the processes of jobchanges to other places with the help of friends who had already left Oarai. Subject 24 left Oarai comparatively earlier than other subjects and is currently working at an automobile factory in Oizumi, Gunma Prefecture. She obtained information about her current job from Mr. B, an undocumented Minahasan worker who was a member of GIII. Later, Subject 24 entered into a contract with the same broker that Mr. B had contracted with, and moved to a new company. Her desire to change jobs could be realized through her connections with an undocumented worker. Thus, ties with undocumented workers can be a decisive factor in job changes among JapaneseMinahasans.
Second job change through ties with family and relatives

Although those who depend on undocumented workers to move to other places for a better job usually obtain higher wages than those who work in seafood processing companies, many people return to Oarai for various reasons. For example, the type of job does not suit them, the actual circumstances of the workplace are different from what they expected, or they feel mentally unstable or lonely without their family and friends.

It is easy for workers to find a job in Oarai again through direct application. However, they are then faced with the problem of finding a place to live. Unless they have saved enough money from their previous jobs to rent a house, they are forced to find someone who can provide them with accommodation. Of course, it would be ideal if they had family members living in Oarai.

Subjects 11, 12, and 13 are brothers, and they are good examples of such a situation. They started live with 37 relatives, the largest group of relatives among all the Minahasans in Oarai.

Subject 11 had been working in a seafood processing company since his arrival, and he was able to speak Japanese fluently. At the time of the interview, he was 
not considering a change in his job or his dwelling. He pointed out several reasons. First, he is a Sansei-a thirdgeneration Japanese descendant. His children, Yonsei (fourth generation), are not allowed to immigrate to Japan because of the legal restriction. ${ }^{11}$ In order to invite his son to Japan as an immigrant, Subject 11 must first become a permanent resident. He assumed that he had to continue working at one place without a long absence and earn the trust of the Immigration Office. ${ }^{12}$ This is the reason that Subject 11 has never returned to his home country, Indonesia, nor changed jobs.

In contrast, Subject 13, who came to Japan in November 2001, worked for three years and five months at a seafood processing company, and began changing jobs in April 2005, staying with his friends and relatives. Finally, in June 2005, he started working in a machinery factory he found through a broker (Mr. C) in Ota, Gunma Prefecture. The broker demanded high mediation charges, and Subject 13 could not obtain good wages, so he returned to Oarai to work in another seafood processing company in August of the same year. He started to live with Subject 11, his brother. He now intends to work at his present company for at least another six months staying at his brother's house. Subject 13 knows why Subject 11 does not change jobs nor move to other places. On the part of Subject 11, he is able to reduce his household expenses by accepting his brother as a lodger. Now the brothers are both satisfied with their arrangements for sharing the place.

At present, Subject 12 is also staying with Subject 11 . His experience was similar to that of Subject 13. In this manner, Japanese-Minahasans often return to live with relatives after working outside Oarai for short periods.

\section{Complicated example of successive job changes of a family}

This is a more complicated example of job changes within a Japanese-Minahasan family. Subjects 1, 2, 3, 4 , and 5 are all members of the $\mathrm{H}$ family. Subject 1 is a Nisei who is the head of the household; his children are Subjects 2, 4, and 5. Subject 3 is Subject 4's wife. There are several other members of the $\mathrm{H}$ family who were not included as subjects in this study. A total of 13 members of the $\mathrm{H}$ family have worked in Oarai.

Like many other Japanese-Minahasans, Subjects 1, 2, 4, and 5 worked at a seafood processing company in Oarai 2000 through 2003. In January 2003, Subject 3 came to Japan to be with her husband, Subject 4, and took a job at the company where her husband was working. In October 2003, Subject 2 quit his first job and returned to his home country. He came back to Japan in January 2004, when he took up another job in Oarai through direct application. Around the same time, Subject 5 also quit his first job, and switched to another industry through a broker, Mr. D. Neither Subject 2 nor Subject 5 used ties with relatives to change jobs. Later, in June 2004, Subject 4 joined the company to which Subject 5 had moved, and in December of the same year, Subjects 2 and 3 also switched to the same company. Later, Subjects 4 and 5 quit the company and began seeking better jobs. Before this, Subject 1 left the company boarding house to live in an apartment house with Subjects 2 and 5, and their spouses. Subjects 3 and 4 , a couple, also moved into the same apartment building, but in a different room.

Toward the end of the year, Mr. E, a Peruvian broker, visited GMIJ, the church to which Subject 2 belonged. Mr.E repeated visiting GMIJ, and invited members to apply for jobs in a machinery industry in Oizumi. Subject 2 applied and got a job at the machinery company in January 2005. Like the systems that mediate employment for Japanese-Latin Americans, Mr. E's office in Oizumi charged a fee for its employment services. Mr. E's service afforded Subject 2 to earn higher wages and obtain insurance, and the latter was satisfied with his earnings and overall treatment at his new job. Later, Subjects 3, 4, and 5 switched to the same company as Subject 2 .

Unlike other members of the $\mathrm{H}$ family, Subject 1 had never changed jobs since his arrival in Japan, and never returned to his home country. In the $\mathrm{H}$ family, Subjects 2, 4, and 5 always consulted Subject 1 , their father, before attempting to change jobs. Although Subjects 2 and 5 were certainly encouraged to change jobs by brokers, Mr. $\mathrm{D}$ and Mr. E, the final decision was made by Subject 1 . Subject 1, the head of the family, thus played an important role in his family's job changes, exerting an influence on every aspect of his family's employment. Furthermore, when one family member changed jobs, his or her siblings followed. This was the strategy adopted by Subject 1, who wished to minimize the risks for family members working outside Oarai. Thus Oarai, where Subject 1 had constructed a bridgehead, functioned as a "bastion" that enabled other family members to advance step by step in the labor market through brokers.

\section{Analyses of relationships between Japanese- Minahasans' strata and their job changes}

The author would like to use Figure 5 in this subsection again and examine six cases applying the social capital theory. Figure 5 shows the subjects situated in a pyramidal hierarchy in relation to their social ties with their companies, relatives, and friends. According to 
the results of the interviews, "extensiveness" was set up in four strata in the hierarchy. The criteria for deciding which of the four strata each subject should be classified into were restricted to the benefits the subject received, in the form of wages and welfare, from his or her company.

Subjects who worked only in the seafood processing industry since their arrival in Oarai were classified to the first (lowest) stratum, as they were considered to receive the lowest wage. Those who found new jobs in industries other than seafood processing in Oarai were grouped in the second stratum, as they got better treatment. The third stratum was for subjects working in industries other than seafood processing outside Oarai, for example, in Tsuchiura and Mito, both in Ibaraki Prefecture, and Oizumi, Gunma Prefecture. These cities have companies that deal in electronics, machinery, and automobile products, and the employees in this stratum are offered better conditions than their counterparts in Oarai.

The fourth stratum, in which brokers receive better treatment than those in any other stratum, represents the upper reachability of the hierarchy. Most of the workers in this stratum are undocumented Minahasans who left Oarai, and work for introducing foreign laborers to companies in other strata, and get large income. No subjects among those interviewed in this paper were classified into the fourth stratum. The area below the first stratum was not taken into consideration.

It is inferred from the examples above that people in two positions are influential over Japanese-Minahasans' job-changings: undocumented Minahasans who had entered the foreign labor market in Japan, and heads of families who have authority to give advice to other members and can offer them a place to return to in case they were not successful outside Oarai.

What drew the author's attention was that hierarchical structures obtained from these results differ from conventional hierarchies. In a thesis on foreign workers in Japan by Inagami et al. (1992), Latin Americans of Japanese origin who hold visas were placed in the upper strata on the grounds that they obtain higher wages and better treatment, while undocumented Asian workers were placed in the lower strata. In this study, however, Japanese-Minahasan subjects who hold visas were placed in the lower strata and those without visas were placed in the upper strata, that is, exactly opposite of JapaneseLatin Americans in Inagami's study. Further, the heads of families might be considered to be in the upper stratum, followed by relatives of Japanese-Minahasans in the middle, and undocumented workers in the lowest stratum. The author's field survey in Oarai, based on the social capital theory, has thus presented a completely different hierarchy from the models suggested by preceding studies.

\section{Conclusion}

The results obtained from this investigation can be summarized as follows. Since 1998, in response to the labor shortage of Oarai's declining seafood processing industry, Japanese-Minahasans and their relatives have been coming to Japan to work. Some Japanese-Minahasans were introduced to their places of employment by Mr. A, who had personal connections with people in North Sulawesi. Since then, with the help of more agents and Japanese relatives, the Japanese-Minahasan population in Oarai has increased considerably.

Many Japanese-Minahasans have had to work at the same company for more than two years after their arrival in order to repay the charges for their voyage to Japan and other necessary procedures. Later, in search of better working conditions and wages, they began to seek jobs at other companies both inside and outside Oarai either independently or with the help of relatives. Actually, the Minahasan population has not completely broken its ties with Oarai. Subjects 1 and 11, for example, continue to reside in Oarai, playing the role of leaders in their communities and reducing the risk concerning family members' job changes. The existence of these family leaders in Oarai encourages other family members to begin gradual expansion. From a spatial point of view, this role allotment provides an impetus for JapaneseMinahasans to live and work in other places, while they maintain connections to Oarai.

This will lead us further to understanding that this expansion by Japanese-Minahasans through role allotment is related to the theory of structural contingency proposition. Japanese-Minahasans, who have social connections with both undocumented workers and heads of their own families, are in the middle stratum of the contingency proposition in the social capital theory. They can set up networking systems rather easily and move to other places in Japan while keeping Oarai as a base. Thus, people who occupy middle strata are able to construct wider networks.

Japanese-Minahasans who have social connections with both undocumented workers and heads of their own families certainly have the widest networks, which corresponds with the contingency proposition. Although Japanese-Minahasans are comparatively new immigrants, those with wider networks can easily secure jobs in 
Japanese society from the viewpoint of contingency propositions. However, their seemingly superior ability to adjust to life in Japan is not as solid and permanent as it appears. As Japanese-Minahasans do not have many opportunities to associate with Japanese people, they cannot develop practical Japanese language skills which would put them more at advantage.

In this paper, the social capital theory was applied to undocumented workers, family leaders, and other Japanese-Minahasans in the pyramidal hierarchy. Japanese-Minahasans have constructed a unique system of job changes influenced by complex factors such as the economic situation in their home country, the demand of the Japanese labor market, and personal ties with their communities and relatives.

For the future, even minor ethnic groups living and working in Japan should be observed from a longterm perspective, with relevant data. It is also essential to examine the specific characteristics of each group while maintaining the necessary level of efficiency and comprehensiveness. In this light, social capital theory is an effective measure.

\section{Acknowledgements}

The author would like to thank the Japanese-Minahasan interviewees for their information and comments. This paper is a part of the author's Master's thesis submitted to the Department of Geography, Graduate School of Science, Tokyo Metropolitan University.

\section{Notes}

1. The reasons why Japanese-Minahasans were employed in seafood processing companies in Oarai are explained in the following documents: "Joyo ARC [ARC for Daily Use]" (Joyo Regional Study Center Inc. Foundation Sep. 2002: 3032), a report published by a private corporation in Ibaraki Prefecture; "Monthly ALTA" (Pacific Asia Resource Center, June 2002: 32-33), an NGO bulletin; and "Shinto-no-Tomo" [Monthly Booklet for Brethren] (The Board of Publications, The United Church of Christ in Japan, Dec. 2003: 36-39), a bulletin published by a Protestant Church.

2. In migration system theory, the unit that has the biggest influence on migration is "not individuals or family members, but relatives and a group of people united through labor experience" (Massey et al. 1987; Tilly 1990: 84; Higuchi 2002). Migration system theory was developed by adopting the social capital theory (Massey and Epinosa 1997; Higuchi 2002).

3. See Lin (2001b: 60). Due to space limitations, an all-inclusive explanation of these seven propositions is not given in this paper. Annotations are added when necessary.
4. The social capital theory cited in this paper is usually used in the context of resource-motivated social relation capital theory, which is one of the social network analyses. This type of social capital theory can be applied to both individuals and groups without considering the characteristics and benefits of social relations (Kanamitsu 2003; Lin 2001b). Accordingly, it may also be appropriate to apply this theory to JapaneseMinahasans in Oarai.

5. The residential distribution of Japanese-Minahasans in Oarai is inferred from the distribution of all foreigners and the author's field survey, as no detailed data for each nationality are yet available.

6. For the religious characteristics and circumstances of establishment for each church, see Okushima (2005).

7. According to the "Educational Statistics Manual 2000/2001" published by the Republic of Indonesia.

8. All the subjects in this study had finished repaying their debts.

9. Others remarked that it was difficult to remember how many times they had changed jobs, because, if day labor was included, the number of changes would amount to more than 30 (Subject 5, for example).

10. The term "broker," generally used by ethnic groups such as Japanese-Brazilians, implies traders who sign a contract for employment. From a legal point of view, these businesses are not allowed to accept any type of payment unless they are formally registered; however, almost all of them charge service or mediation fees (Tezuka 1995). Japanese-Minahasans do not particularly evade employment through brokers. In Indonesia, the broker system is already at work to find work in Singapore, Malaysia, and Saudi Arabia (Spaan 1994). In the case of Japanese-Minahasans, "broker" implies not only traders but also mediators in general who receive regular income from clients. Thus, in the preliminary stage of this paper, the term "broker" was intended to refer to people involved in a wider range of mediating business rather than just being traders who offer contracts for employment. At the concluding stage of the investigation, it became apparent that the "brokers" mentioned by Japanese-Minahasans and those mentioned by other groups of foreign workers were largely synonymous.

11. Japanese Yonsei under 17 years of age are allowed to stay in Japan under the protection of their parents (Sansei). When Subject 11's son became 18 years old, Japanese law does not allow him to stay in Japan for an extended period of time.

12. This assumption of Subject 11 is based on the explanation given to him by the Immigration Office. Criteria for screening permanent residents fluctuate frequently according to various interpretations of the law. Thus, it is not necessarily true that foreigners can obtain permanent residency more easily by working at the same company for a long period of time.

\section{References}

Arango, J. 2000. Explaining migration: A critical view. International Social Science Journal 165: 283-296.

Higuchi, N. 2002. Organizational basis of international migration: Toward a comparative analysis of migration systems. Soshioroji 
(Sociology) 47(2): 55-71.

Hirota, Y. 2003. Esunishiti to toshi (Ethnicity and city). Tokyo: Yushindo. (J)

Inagami, T., Kuwahara, Y. and People's Finance Corporation Research Institute 1992. Gaikokujin rodosha o senryokuka suru chusho kigyo (Medium and small companies that use foreign laborers strategically). Tokyo: Medium and Small Companies Research Center. (J)

Kajita, T. and Iyotani, T. eds. 1992. Gaikokujin rodosharon: Genjo kara riron e (Foreign laborer theory: From reality to theory). Tokyo: Kobundo. (J)

Kanamitsu, J. 2003. Shakai nettowaku bunseki no kiso (Explorations in social networks). Tokyo: Keiso Shobo. (J)

Kataoka, H. 2004. The formation, development of ethnic business and local community in Hamamatsu. Annals of the Japan Association of Economic Geographers 50: 1-25. (JE)

Kataoka, H. 2005. Development of ethnic solidarity based on ethnic businesses: The Brazilian community in Hamamatsu City, Japan. Geographical Review of Japan 78: 387-412. (JE)

Lee, L.H. 2002. Job search and network dynamics: The socioeconomic transformation of Koreans in Japan. Geographical Review of Japan 75: 183-194. (JE)

Lin, N. 2001a. Guanxi: A conceptual overview. In The Chinese triangle of mainland China, Taiwan and Hong Kong: Comparative institutional analyses, ed., A. Y. So, N. Lin and D. Poston, 153-166. Westport, CT: Greenwood Press.

Lin, N. 2001b. Social capital: A theory of social structure and action. New York: Cambridge University Press.

Mabogunje, A. L. 1970. System approach to a theory of rural-urban migration. Geographical Analysis 2: 1-17.

Massey, D., Alarcón, R., Durand, J. and González, H. 1987. Return to Aztlan: The social process of international migration from Western Mexico. Berkeley: University of California Press.
Massey, D. and Epinosa, K. E. 1997. What's driving Mexico-U.S. migration. Science 237: 733-738.

Meguro, U. 2005. Establishment of the Japanese-Indonesian community and their employment system in Oarai Town, Ibaraki. Intercultural Communication Studies 17: 49-78. (JE)

Okushima, M. 2005. Introduction to a special issue: International trends of Indonesian migrant workers, and their employment system in Japan. Intercultural Communication Studies 17: 1-47. (JE)

Onai, T. and Sakai, E. eds. 2001 Nikkei burajiru jin no teijuka to chiiki shakai (Settlement and local society of Japanese Brazilians). Tokyo: Ochanomizu-shobo. (J)

Portes, A. 1995. Economic sociology and the sociology of immigration: A conceptual overview. In The economic sociology of immigration, ed. A. Portes, 1-41. New York: Russell Sage Foundation.

Portes, A. 1996. Immigrant America: A portrait. Berkeley: Cambridge University Press.

Roberts, B. 1994. Informal economy and family strategies. International Journal of Urban and Regional Research 18: 6-23.

Spaan, E. 1994. Taikongs and calos: The role of middlemen and brokers in Javanese international migration. International Migration Review 28(1): 93-113.

Tezuka, K. 1995. Gaikokujin to ho (Foreigners and Law). Tokyo: Yuhikaku. (J)

Tilly, C. 1990. Transplanted networks. In Immigration reconsidered: History, sociology, and politics, ed. V. Yans-McLaughlin, 79-95. New York: Oxford University Press.

Tirtosudarmo, R. 2005. The making of a Minahasan community in Oarai: Preliminary research on social institutions of the Indonesian migrant workers in Japan. Intercultural Communication Studies 17: 105-138.

(J): written in Japanese

(JE): written in Japanese with English abstract 